\title{
Review of the effects of technical assistance on program, organization and system change
}

\author{
Carl J. Dunst, Kimberly Annas, Helen Wilkie, Deborah W. Hamby
}

Orelena Hawks Puckett Institute, North Carolina, USA

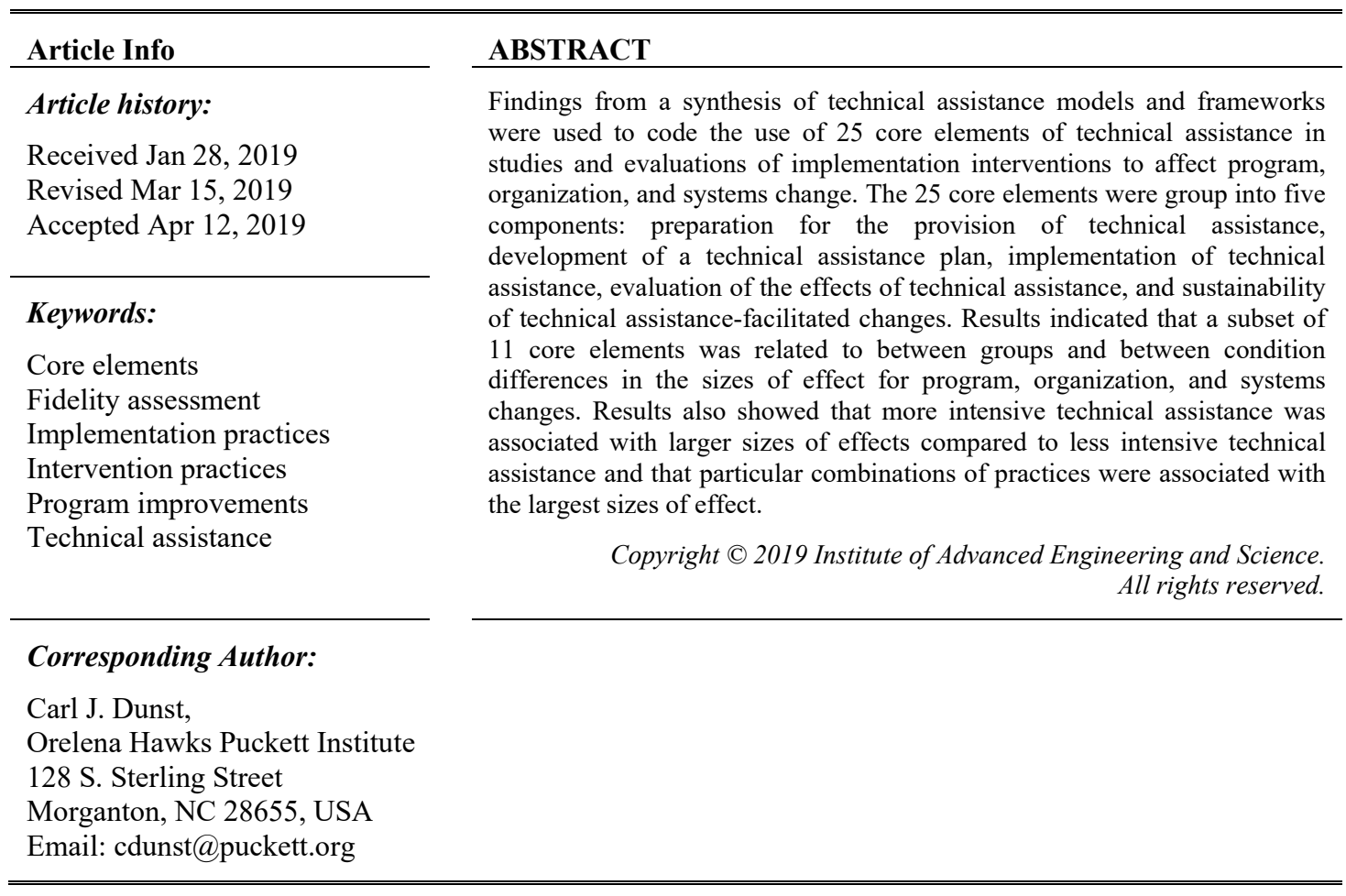

\section{INTRODUCTION}

Technical assistance, in the broadest possible use of the term, refers to professional development, coaching and mentoring, consultation, and other supports provided to programs and organizations to affect change or adoption of evidence-based or innovative practices [1-3]. There is, however, no commonly accepted definition of technical assistance as noted by a number of experts $[1,4]$. West et al. concluded, based on an extensive review of the effectiveness of technical assistance interventions, that "We were unable to find a commonly accepted definition of technical assistance in the published literature" [4].

The lack of a commonly accepted definition of technical assistance led a number of experts to propose working definitions of the term. A content analysis of these working definitions finds a number of common elements; namely, capacity building [4,5], quality implementation [6], and quality improvement [7]. West et al. for example, defined technical assistance as "A dynamic, capacity-building process for designing or improving the quality, effectiveness, and efficiency of specific programmes, research, services, products, or systems" [4]. Katz and Wandersman proposed a similar definition: "Technical assistance is an individualized and hands-on approach to capacity-building in organizations and communities" [5].

A working definition of technical assistance, however, is only a first step toward operationalization of the term [8]. A second crucial step is defining the practices, tasks, steps, activities, elements, etc. that comprise technical assistance. This has been attempted by a number of investigators $[5,6,9,10]$ where findings were used to identify the core elements of technical assistance models and frameworks [11]. Twenty-five models and frameworks in early childhood intervention, education, health care, developmental disabilities, pregnancy prevention, child welfare, and youth development were systematically examined to 
identify the core elements of the models and frameworks. Five components were identified with each component including between 4 and 6 core elements. The five components are (1) preparation for the provision of technical assistance, (2) the development of a technical assistance plan, (3) implementation of technical assistance, (4) evaluation of the effects of technical assistance, and (5) the sustainability of the changes, innovations, improvements, etc. facilitated by technical assistance.

Table 1 includes the descriptions of each core element in the five technical assistance components. The use or inclusion of each core element, as well as combinations of elements, in the studies and evaluations in our review were examined as factors contributing to the outcomes of technical assistance in terms of adoption and use of targeted intervention practices. Technical assistance was conceptualized as an implementation practice that included specific sets of activities (core elements) to affect changes in a program, organization, or systems [12] where variations in technical assistance would be expected to be related to variations in reported or observed changes in a program, organization, or systems [13]. Stated differently, the core elements are the types of practices that technical assistance providers use to achieve desired program, organization, or system change.

Studies and evaluations of the effects of technical assistance can be divided into two types of implementation practices: Practices that focus on changes or improvements in a program, organization, or system [14-16] and practices that focus on coalition building [17, 18] or community development [19]. The studies and evaluations examined in the present review included investigations where technical assistance was used to influence the adoption and use of evidence-based, innovative, or recommended practices in programs, organizations, or systems. Studies and evaluations of technical assistance for coalition building or community development were beyond the scope of the review.

Existing reviews of technical assistance studies and evaluations are primarily limited to descriptions of the technical assistance practices used to affect changes in programs, organizations, or systems $[5,6,10$, $15,20]$. One exemption is a review by West et al. [4]. These investigators included descriptive findings of both the core elements and the outcomes of technical assistance but did not relate the use of the practices to any of the study. Durlak and DuPre [3] as well included findings for both the degree of implementation of targeted practices and the study outcomes. Neither of these reviews, however, included attempts to quantitatively relate the use of technical assistance practices to any study or evaluation outcomes.

The extent to which the core elements in Table 1 were used in technical assistance studies and evaluations and were related to report or observed changes in program, organization, or systems practices was the focus of the review described in this paper. This was accomplished by coding the use of the 25 technical assistance core elements in Table 1 and relating the use of the core elements to differences in the technical assistance study and evaluation outcomes. This was done in a number of ways in order to unpack the influences of technical assistance to identify the particular core elements and conditions under which the core elements were associated with observed or report program, organization, or system changes. The expected outcome was the identification of the particular core elements or combinations of elements that proved most important in terms of explaining study and evaluation outcomes.

Review of the effects of technical assistance on program, organization, and system change (Carl J. Dunst) 
Table 1. Core elements of technical assistance

\begin{tabular}{|c|c|}
\hline \multicolumn{2}{|c|}{ Core elements } \\
\hline \multicolumn{2}{|c|}{ Preparation for technical assi } \\
\hline 1 . & Needs assessment \\
\hline 2 . & Decision-making \\
\hline 3. & Visioning \\
\hline 4. & Readiness for change $(b$ \\
\hline 5 . & Organizational capacity \\
\hline & nical assistance plan \\
\hline 1. & Goals and objectives \\
\hline 2. & Intervention practices \\
\hline
\end{tabular}

3. Fit assessment

4. Logic model or theory of change

5. TA resources

6. Staff roles and responsibilities

Technical assistance implementation

1. TA provider credibility

2. Professional development

3. Coaching and mentoring

4. Consultation

5. TA provider support/feedback

Technical assistance evaluation

1. Process evaluation Definitions of terms

Process for determining the gap between current conditions, practices, or outcomes and desired conditions, practices, or outcomes

Process for involving program staff in identifying, among alternatives, the options or priorities that best fit with the organization's mission or goals

Process for determining what an organization would do or "look like" if it was to make desired changes

Staff commitment to change program, organizational, or systems practices to improve effectiveness in order to achieve desired changes or outcomes

Ability of an organization to commit the human, program, and other resources needed for a program, organization, or system changes to produce desired practices

The immediate (objectives) and long-term (goals) program changes and outcomes that are the desired benefits of TA

The particular evidence-based intervention practice or best practices identified (targeted) to produce desired program, organizational, or systems change

Determining how well the targeted intervention practice matches (fits) the program or organization's mission, priorities, desired changes, staff beliefs, etc. and how well the proposed TA practices also fit the program ecology

A description or graphic representation of the relationship between desired program, organizational, or system inputs and resources; the intervention practices, actions, or activities to affect desired change; and the intended outputs and outcomes of use of the practices, actions, or activities

TA resources made available to and/or provided to program staff to improve the use of targeted evidence-based or best practices

Specification of the roles and responsibilities of individual staff, and how enactment of those roles and responsibilities, are expected to contribute to desired change

Practices used by a TA provider to establish staff trust, respect, rapport, and beliefs that the provider is acting in the best interests of the program and staff receiving TA

The evidence-based professional development practices used by a TA provider to build and strengthen staff, program, organization, and systems capacity to use targeted intervention practices

TA provider use of either or both coaching and mentoring as part of the provision of TA and in interactions with staff to build and strengthen their capacity to use targeted intervention practices

Tailored responses to individual staff, small groups of staff members, and other program staff in response to questions, concerns, etc. about staff adoption and use of targeted intervention practices

TA provider nonjudgmental acknowledgment, encouragement, and feedback on staff efforts toward and accomplishment of changing program practices consistent with the objectives and goals of the plan

Methods for determining if the practices, activities, or interventions specified (in a theory of change or logic model) were implemented as planned and resulted in identifiable outputs

Int. J. Eval. \& Res. Educ. Vol. 8, No. 2, June 2019: 330 - 343 
Table 1. Core elements of technical assistance (Continued)

\begin{tabular}{ll}
\hline 2. Outcome evaluation & Methods of determining if the practices, activities, or actions have \\
resulted in desired changes and affect progress or benefits in the \\
target group(s) of a program, organization, or systems
\end{tabular}

3. Fidelity of use of intervention practices

Extent to which the key characteristics of targeted practices that are the focus of TA were implemented in a manner in which they were designed to be used or delivered

4. Fidelity of use of TA practices

Extent to which the core elements of TA were used as intended and in a consistent manner with program staff responsible for use of the intervention practice constituting the focus of TA

5. Lessons learned

Knowledge gained from the use of TA to promote staff use of the targeted intervention practice(s) constituting the focus of TA and the use of that information to make changes or improvements in the overall implementation of program activities

Sustainability of TA-facilitated change

1. Capacity-sustaining activities

2. Continuous quality improvement

3. Ongoing TA provider support

4. Follow-up activities
The program, organization, or systems resources, activities, and professional supports that are used to sustain or maintain the changes that have been put into place as a result of TA-related practices

Processes used to ensure ongoing improvements in a program, organization, or systems that were the focus of TA

Procedures used to provide either or both informal and formal TA supports to program staff after the completion of TA-related activities

Planned activities used to provide program staff opportunities to share concerns and accomplishments and to obtain input, feedback, suggestions, etc. from a TA provider

\section{METHOD}

\subsection{Search strategy}

Technical assistance studies and evaluations were located through searches of ERIC, PsycInfo, ProQuest Central, MEDLINE, and Google Scholar. These were supplemented by searches of the reference sections of all retrieved papers and reports as well as by searches of an EndNote library maintained by our Institute.

Candidate studies and evaluations were located using the search terms "technical assistance" AND "study OR evaluation OR investigation OR research." Separate searches were conducted in the above sources for the search terms in the titles, abstracts, keywords, and the bodies of text since technical assistance is not a controlled vocabulary term in any of the electronic databases except MEDLINE. Results were sorted by relevance and the full texts of all retrieved documents were examined until no new candidate studies or evaluations were found.

\subsection{Inclusion criteria}

Studies and evaluations were included if an investigation examined the effects of technical assistance on the adoption and use of evidence-based, evidence-informed, innovative, or other recommended practices as part of program, organization, or systems change. Studies and evaluations of technical assistance that included only program recipient outcomes were excluded, as were recipient outcomes in studies and evaluations including both practice and program recipient outcomes. Eligible studies and evaluations needed to include between groups or between condition comparisons that permitted calculations of mean difference effect sizes for changes or improvements in targeted practices.

Studies and evaluation that met the inclusion criteria provided individualized technical assistance to targeted programs or organizations that included some type of training, professional development, coaching, mentoring, or other types of supports to promote practitioners' adoption and use of the practices that were the focus of technical assistance. The types of the technical assistance in each study or evaluation were examined to discern the intensity of the implementation practices to affect program, organization, or systems change. Fixsen, Blase, Horner and Sugai's [21] definition of intensive technical assistance was used to group the studies and evaluations into either intensive or less intensive approaches based on five key features (clarity, frequency, intensity, duration, and integrity). Clarity and integrity was measured in terms of the use of these particular core elements of technical assistance and frequency, intensity, and duration was determined from

Review of the effects of technical assistance on program, organization, and system change (Carl J. Dunst) 
an analysis of each of the study and evaluation reports. Half of the studies and evaluations (52\%) were categorized as intensive technical assistance interventions, and half of the studies and evaluations were categorized as less intensive technical assistance.

Exclusion criteria as noted above, studies and evaluations that focused on coalition building or community development were also excluded from the review. Studies and evaluations that did not include a sufficiently detailed description of the make-up of technical assistance to affect program, organization, or systems change were also excluded. The latter typically included papers and reports that stated that the implementation practices included technical assistance but there was no description of the core elements of technical assistance used in the studies or evaluations.

\subsection{Data preparation}

A structured data coding form for each of the Table 1 core elements was used to code the presence or absence of the core elements in the studies and evaluations by searching electronic versions of each retrieved paper or report. The coding form included primary, secondary, and related terms for each core element (fidelity, adherence, or integrity) to identify all relevant core elements. The electronic searches were supplemented by reviewer examination of each study and evaluation to also be assured no core elements were missed. Ten of the 25 investigations (40\%) were randomly selected and coded independently by two authors for calculating interrater agreement. Agreement was computed as the number of agreements divided by the number of agreements plus non-agreements. The median percent of agreement was 92 (Range $=84$ to 96). Disagreements were resolved by an author noting the presence of a core element not identified by other authors until there was $100 \%$ agreement.

The types of comparisons in the studies and evaluations were coded in terms of the research design used to determine the relationships between the core elements and sizes of effects for between group or between condition comparisons. Three different types of comparisons or contrasts were used to establish the effects of technical assistance: Between group posttest differences, between condition comparisons, and pretest-posttest differences. The dependent measures included the adoption and use of the practices that were the focus of program, organization, or systems change. Half of the investigations $(52 \%)$ included only one outcome measure and the other half included multiple outcome measures.

\subsection{Data analysis}

Six sets of analyses were conducted to identify the relationships between the core elements and study and evaluation outcomes. We first determined for all 25 investigations which core elements were used in each of the studies and evaluations. Second, we calculated the average mean difference effect sizes and $95 \%$ confidence intervals for the outcomes in the studies and evaluations in the research reports to establish the efficacy of technical assistance. Third, we identified which particular core elements included in the studies and evaluations were associated with positive sizes of effect. Fourth, we evaluated the effects of the intensity of technical assistance on the sizes of effects for program, organization, and systems change. Fifth, we determined which core elements or combinations of core elements were associated with the sizes of effects for core element-outcome relationships. Sixth, we evaluated the influences of the two types of fidelity core elements (technical assistance and intervention) on the sizes of effects for program, organization, and systems changes to determine if hypothesized relationships were supported by the analyses of the effects of technical assistance on the study and evaluation outcomes [13, 21, 22].

Pattern matching [23] was used to identify which technical assistance core elements or combinations of elements used as implementation practices were related to the sizes of effects for the outcomes. A particular type of process pattern matching was used to determine, among all core elements, which elements were associated with positive outcomes in studies and evaluations that differed in terms of research designs and types of outcome measures [24]. Observed or obtained patterns were mapped onto the technical assistance study and evaluation outcomes as a basis for establishing core element outcome relationships.

In addition to pattern matching, other analyses were conducted to identify the relationships between (1) the combined use of the core technical assistance components and the study and evaluation outcomes, (2) different levels of technical assistance and the study and evaluation outcomes, and (3) specific combinations of core elements and the study and evaluation outcomes. The latter post hoc follow-up analyses were informed by the results of all of the preceding analyses.

\section{RESULTS}

\subsection{Types of studies and evaluations}

One hundred and fifty-five (155) technical assistance papers and reports were located and each examined in terms of the descriptions of core elements, the practices constituting the focus of investigation, 
research designs, and the inclusion of data to compute mean difference effect sizes. Twenty-five (25) of the 155 studies and evaluations met the inclusion criteria. The majority of investigations were conducted in early childhood intervention programs or schools $(70 \%)$. The other studies and evaluations were conducted in health care, human services, family and childcare programs, and community-based programs. Appendix A includes the list of 25 studies and evaluations.

The practices that were the focus of technical assistance included school-wide behavior supports, family systems intervention practices, classroom practices, care coordination, teacher-child interactions, inclusion practices, teaching quality, curricular practices, early childhood physical activity practices, child and family support, and different kinds of behavior management interventions. Most of the investigators stated that the practices that were the focus of technical assistance were evidence-based or evidence-informed interventions. Several other investigators stated that the practices that were the focus of technical assistance were innovative intervention practices.

The outcomes for measuring adoption of, adherence to, or improved use of the intervention practices constituting the focus of investigation included different measures of intervention fidelity [25, 26-28] and changes or improvements in the use of the practices constituting the focus of investigation [29, 30-32]. The majority of outcome measures included direct observations of expected changes or improvements in targeted practices whereas a number of investigations used rating scales for measuring observed or reported changes.

Information included in the studies and evaluations permitted 17 between group comparisons, 12 between condition comparisons, and 21 pretest-posttest comparisons. The between group posttest only design studies and evaluations were either experimental or quasi-experimental investigations where the use of technical assistance to affect changes in a program, organization, or systems was compared to outcomes in a program, organization, or systems not receiving technical assistance. The comparative condition design studies and evaluations included investigations where the effects of technical assistance were compared to less intensive technical assistance or alternative conditions (e.g., workshops). The pretest-posttest design evaluations compared program or organization outcomes before and after the provision of technical assistance.

\subsection{Core elements}

Table 2 includes the number and percent of core practices (elements) used in the 25 investigations. The core elements used most often in the technical assistance investigations were professional development $(100 \%)$, explicit identification of targeted intervention practices $(96 \%)$, technical assistance provider consultation (84\%), identification of technical assistance and intervention goals and objectives $(80 \%)$, technical assistance provider support and feedback (80\%), needs assessment (76\%), technical assistance recipient decision-making $(76 \%)$, and a process evaluation for determining if expected changes were achieved (76\%). This constellation of technical assistance practices indicates that among the 25 core elements, these particular practices "stand out" as most frequently used for the planning, delivery, and evaluation of the effects of efforts to affect program, organization, or systems change in the investigations in the review.

Inasmuch as intervention practice fidelity is an important measure for determining if a practice was adopted and used as intended, it was somewhat surprising to find that about one-third of the investigations did not include an explicit description of this type of measure. It was also surprising to find that only about half of the investigations included assessment of readiness to change since nearly all of the intervention practices that were the focus of technical assistance were offered to program staff rather than staff deciding the practices that would be the focus of technical assistance. It was not surprising to find that only about onethird of the investigations assessed fidelity of use of the technical assistance practices. This was the case since this type of fidelity has only recently been recognized as important for evaluating the effects of implementation practices on program, organization, or systems change [21, 22].

\subsection{Effectiveness of technical assistance}

The 25 studies and evaluations all included outcomes measures that provided evidence for whether technical assistance was associated with observed or reported changes. Table 3 shows the mean difference effect sizes and $95 \%$ confidence intervals for the three types of research design used in the investigations. Technical assistance was related to changes or improvements in the use of targeted practices regardless of the type of comparison as evidenced by statistically significant $Z$-tests for the between group or between condition comparisons.

The fact that the mean difference effect sizes for the between condition comparisons is smaller than those for the other two types of study designs was not unexpected. Whereas the comparisons for the between group and pretest-posttest studies both included contrasting groups or conditions not involving any technical assistance, the between condition comparisons involved some type of technical assistance vs. an alternative

Review of the effects of technical assistance on program, organization, and system change (Carl J. Dunst) 
type of professional development. The latter, therefore, would have been expected to have had at least a small effect on the measures constituting the focus of investigation which would have influenced the between condition differences.

Table 2. Core elements and practices included in the descriptions of the technical assistance

\begin{tabular}{|c|c|c|}
\hline Core elements & Number & Percent \\
\hline \multicolumn{3}{|l|}{ Preparation for technical assistance } \\
\hline Needs assessment & 19 & 76 \\
\hline Decision-making & 19 & 76 \\
\hline Readiness for change & 14 & 56 \\
\hline Organizational capacity & 7 & 28 \\
\hline Visioning & 4 & 16 \\
\hline \multicolumn{3}{|l|}{ Technical assistance plan } \\
\hline Intervention practices & 24 & 96 \\
\hline Goals and objectives & 20 & 80 \\
\hline Technical assistance provided resources & 17 & 68 \\
\hline Logic model or theory of change & 10 & 40 \\
\hline Staff roles and responsibilities & 10 & 40 \\
\hline Fit assessment & 8 & 32 \\
\hline \multicolumn{3}{|l|}{ Technical assistance implementation } \\
\hline Professional development & 25 & 100 \\
\hline Technical assistance provider consultation & 21 & 84 \\
\hline Technical assistance provider support/feedback & 20 & 80 \\
\hline Coaching and mentoring & 16 & 64 \\
\hline Technical assistance provider credibility & 7 & 28 \\
\hline \multicolumn{3}{|l|}{ Technical assistance evaluation } \\
\hline Process evaluation & 19 & 76 \\
\hline Intervention practice fidelity & 17 & 68 \\
\hline Outcome evaluation & 13 & 52 \\
\hline Technical assistance practice fidelity & 9 & 36 \\
\hline Lessons learned & 5 & 20 \\
\hline \multicolumn{3}{|l|}{ Sustainability of technical assistance-facilitated change } \\
\hline Ongoing technical assistance provider supports & 17 & 68 \\
\hline Capacity-sustaining activities & 14 & 56 \\
\hline Follow-up technical assistance activities & 13 & 52 \\
\hline Continuous quality improvement & 8 & 32 \\
\hline
\end{tabular}

Table 3. Mean difference effect sizes and $95 \%$ confidence intervals for the influences of technical assistance on adoption and use of targeted practices

\begin{tabular}{cccccc}
\hline Type of comparison & $\begin{array}{c}\text { Number } \\
\text { of effects }\end{array}$ & $\begin{array}{c}\text { Mean effect } \\
\text { size }\end{array}$ & 95\% CI & Z-test & $p$-value \\
\hline Between group differences & 17 & .82 & $.38,1.25$ & 3.98 & .0001 \\
Between condition differences & 13 & .58 & $.45, .70$ & 10.06 & .0000 \\
Pretest-posttest differences & 21 & .99 & $.58,1.41$ & 5.01 & .0000 \\
\hline
\end{tabular}

NOTE. CI=confidence interval.

\subsection{Pattern matching}

Each of the studies and evaluations for each type of research design was examined to identify which core practices were most often described in the reports and were associated with positive outcomes as evidenced by the sizes of effects for the between group or between condition comparisons. Inasmuch as different investigators used different terminology to describe the same or very similar core elements, those practices that had the same purpose (e.g., needs assessment and decision-making; technical assistance provider consultation and support) were combined for the pattern matching analyses.

Eleven of the 25 core elements were incorporated in those studies and evaluations that were associated with positive program, organization, or systems change. These are shown in Table 4 . In the 25 studies and evaluations, with only a few exceptions, $75 \%$ to $100 \%$ of the investigations included these particular core elements. The results show which particular technical assistance practices were ones most frequently included in the studies and evaluations.

The core elements considered least often in the studies and evaluations, regardless of research design, were visioning, lessons learned, establishing technical assistance provider credibility, and evaluating organizational capacity to adopt and use targeted intervention practices. Other core elements infrequently considered in the studies and evaluations were an assessment of how well the targeted intervention practices

Int. J. Eval. \& Res. Educ. Vol. 8, No. 2, June 2019: 330 - 343 
made sense (fit) in terms of a program or organization's mission or philosophy and fidelity of use of the technical assistance practices to affect program, organization or systems change.

Table 4. Percent of studies and evaluations including technical assistance (TA) core elements for positive changes in the use of targeted intervention practices

\begin{tabular}{|c|c|c|c|}
\hline \multirow[b]{2}{*}{ Core elements } & \multicolumn{3}{|c|}{ Type of design } \\
\hline & $\begin{array}{c}\text { Between } \\
\text { group }\end{array}$ & $\begin{array}{l}\text { Between } \\
\text { condition }\end{array}$ & $\begin{array}{l}\text { Pretest- } \\
\text { posttest }\end{array}$ \\
\hline \multicolumn{4}{|l|}{ Technical assistance preparation } \\
\hline Needs assessment/decision-making & 100 & 100 & 100 \\
\hline \multicolumn{4}{|l|}{ Technical assistance plan } \\
\hline Goals and objectives & 100 & 100 & 73 \\
\hline Intervention practices & 100 & 75 & 67 \\
\hline TA resources & 75 & 75 & 93 \\
\hline \multicolumn{4}{|l|}{ Technical assistance implementation } \\
\hline Professional development & 100 & 100 & 100 \\
\hline TA provider consultation/support/feedback & 100 & 100 & 67 \\
\hline Coaching and mentoring & 75 & 75 & 53 \\
\hline \multicolumn{4}{|l|}{ Technical assistance evaluation } \\
\hline Intervention practice fidelity & 100 & 75 & 53 \\
\hline Process evaluation & 89 & 100 & 67 \\
\hline \multicolumn{4}{|l|}{ Technical assistance sustainability } \\
\hline Follow up/ongoing support & 78 & 100 & 80 \\
\hline Capacity-building activities/CQI & 67 & 100 & 67 \\
\hline
\end{tabular}

NOTE. CQI= Continuous quality improvement.

\subsection{Technical assistance intensity}

The studies and evaluations were each examined to determine if the intensity of technical assistance was related to differences in the sizes of effects for between group and between condition comparisons. Table 5 shows the results for both research design and intensity of technical assistance. Several things can be discerned from these findings. First, regardless of research design or intensity of technical assistance, the implementation practices had positive effects on program, organization or systems change as evidenced by the $95 \%$ confidence intervals not including zero and statistically significant $Z$ - tests. These findings indicate that technical assistance was effective in terms of having observed or reported changes compared to participants not receiving technical assistance or another type of training. Second, more intensive technical assistance was associated with larger sizes of effect compared to less intensive technical assistance. In all three sets of analyses, the average effect sizes for more intensive technical assistance were considerably larger and statistically different than the average effect sizes for less intensive technical assistance for the between group, $t=3.53, p=.0031, d=1.78$, between condition, $t=2.52, p=.028, d=1.47$, and pretest-posttest, $t=3.47, p=.003, d=1.52$, comparisons. The results indicate that the influences of technical assistance on the observed or reported program, organization, or system change were moderated by the intensity of the implementation practices for promoting the use of targeted intervention practices.

Table 5. Average effect sizes and 95\% confidence intervals (CI) for intensive vs. less intensive technical assistance (TA)

\begin{tabular}{lccccc}
\hline Type of comparison & $\begin{array}{c}\text { Number of } \\
\text { effects }\end{array}$ & $\begin{array}{c}\text { Mean effect } \\
\text { size }\end{array}$ & $95 \% \mathrm{CI}$ & Z-test & $p$-value \\
\hline Between group differences & & & & & \\
Intensive TA & 6 & .56 & $.48,2.65$ & 3.72 & .0002 \\
Less intensive TA & 11 & .41 & $.20, .62$ & 4.40 & .0000 \\
Between condition differences & 5 & .73 & $.57, .89$ & 12.75 & .0000 \\
Intensive TA & 8 & .48 & $.32, .64$ & 7.07 & .0000 \\
Less intensive TA & & & & & .0000 \\
Pretest-posttest differences & 11 & 1.52 & $.89,2.16$ & 5.36 & .0004 \\
Intensive TA & 10 & .41 & $.15, .68$ & 3.52 & \\
Less intensive TA & & & & & \\
\hline
\end{tabular}

The extent to which different sets of core elements were associated with the differences in Table 5 was determined by using technical assistance intensity as a grouping variable and the total number of core elements in each of the five technical assistance components as dependent variables in a series of between group $t$-test comparisons. Table 6 shows the results for the two levels of intensity of technical assistance.

Review of the effects of technical assistance on program, organization, and system change (Carl J. Dunst) 
Less intensive approaches to technical assistance included more preparation core elements compared to intensive approaches to technical assistance as evidenced by a statistically significant $t$-test and a medium size of effect for the between condition comparison. In contrast, more intensive approaches to technical assistance included more evaluation core elements compared to less intensive approaches to technical assistance also as evidenced by a statistically significant $t$-test and a large size of effect for the between condition comparison.

Table 6. Mean number of core elements in the intensive and less intensive technical assistance (TA) studies

\begin{tabular}{|c|c|c|c|c|c|c|c|}
\hline \multirow[b]{2}{*}{ Core Elements } & \multicolumn{2}{|c|}{ Intensive TA } & \multicolumn{2}{|c|}{ Less intensive TA } & \multirow[b]{2}{*}{$t$-test } & \multirow[b]{2}{*}{$p$-value } & \multirow[b]{2}{*}{ Cohen's $d$} \\
\hline & Mean & SD & Mean & SD & & & \\
\hline Preparation $(5)^{\mathrm{a}}$ & 2.18 & 0.91 & 2.83 & 0.93 & 2.49 & .0164 & .71 \\
\hline Planning (6) & 3.45 & 0.86 & 3.69 & 1.00 & 0.88 & .3827 & .26 \\
\hline Implementation (5) & 3.64 & 1.09 & 3.93 & 1.28 & 0.87 & .3906 & .24 \\
\hline Evaluation (5) & 2.91 & 1.23 & 1.97 & 1.15 & 2.82 & .0070 & .79 \\
\hline Sustainability (4) & 1.82 & 1.05 & 2.21 & 0.90 & 1.42 & .1624 & .40 \\
\hline
\end{tabular}

${ }^{a}$ Number of core elements each type of technical assistance practice.

Follow-up Chi-square analyses for 2 Between Group (Intensive Technical Assistance vs. Less Intensive Technical Assistance) X 2 Between Core Element (Included vs. Not Included) comparisons were used to identify the sources of the between group differences. More of the less intensive approaches to technical assistance included assessment of the organizational capability core element compared to the more intensive approaches to technical assistance, $\chi^{2}=6.76, p=.009, d=.78$. More of the intensive approaches to technical assistance included assessment of the outcome evaluation core element, $\chi^{2}=7.32, p=.007, d=.82$, and the measurement of fidelity of technical assistance core element, $\chi^{2}=6.50, p=.011, d=.76$, compared to the less intensive approaches to technical assistance.

\subsection{Fidelity assessment}

A particular interest as part of unpacking the effects of technical assistance on the sizes of effects for program, organization, and system changes was the influences of the inclusion of the fidelity of intervention practices and the fidelity of technical assistance core elements in the studies and evaluations. The investigations were grouped into those studies and evaluations including both fidelity core elements $(\mathrm{N}=9)$, those including either of the two fidelity core elements $(\mathrm{N}=9)$, and those including neither of the two fidelity core elements $(\mathrm{N}=7)$. Because the sizes of effects differed as a function of research design (Table 3 ), the effect sizes for each of the three types of contrasts or comparisons were centered where the centered sizes of effects were used as the dependent measures in a 3 Between Group AVOVA with a linear contrast.

The results from the analysis are shown in Figure 1. A downward pattern in the sizes of effects was found for the inclusion or exclusion of the two fidelity core elements. The inclusion of both core elements was associated with the largest size of centered effect sizes and the exclusion of both core elements was associated with the smallest size of centered effects. The Cohen's $d$ for the downward linear trend was $d=.58$.

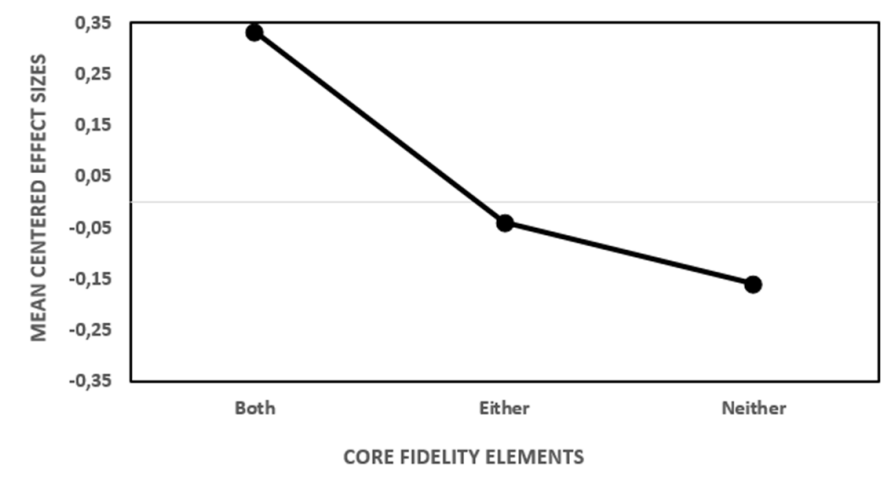

Figure 1. Studies and evaluations including fidelity of both implementation (technical assistance) and intervention, either of the two types of fidelity, and neither of the two types of fidelity measures

Int. J. Eval. \& Res. Educ. Vol. 8, No. 2, June 2019: 330 - 343 


\section{DISCUSSION}

Results from the review of technical assistance studies and evaluations highlighted a number of core elements that were associated with between group and between condition differences in the sizes of effect for technical assistance implementation interventions. The particular core elements that were used in the largest number of studies and evaluations were needs assessment and practitioner decision making; professional development and technical assistance provider supports; process evaluation and assessment of intervention practice fidelity; and follow-up and ongoing technical provider supports to sustain observed or reported change.

The intensity of technical assistance used in the studies and evaluations was related to differences in the sizes of effects for changes or improvements in the use of targeted intervention practices, regardless of the particular practices that were the focus of investigation. More intensive technical assistance had more robust effects on the study and evaluation outcomes compared to less intensive technical assistance. Followup analyses found that studies and evaluations that included fidelity of both technical assistance practices and intervention practices were investigations that had the largest sizes of effects compared to investigations that paid less attention to these two core elements of technical assistance.

Findings from the review both add to an understanding of the core elements of technical assistance that proved most important in terms of explaining the adoption and use of evidence-based and evidenceinformed intervention practices. Durlak and DuPre [3], West et al. [4], and others [5, 7] have extensively investigated the published literature to identify core technical assistance practices and the relationships between the practices and outcomes in studies of efforts to promote adoption and use of evidence-based and evidence-informed practices. The latter has been accomplished primarily by descriptive analyses of technical assistance-intervention practice relationships.

The review described in this paper included quantitative analyses of the manner in which core technical assistance practices were related to study and evaluation outcomes. An iterative data analysis procedure was used to identify which core elements proved most important in terms of the sizes of effects for the adoption and use of intervention practices constituting the focus of technical assistance. The review, therefore, differed from previous syntheses of technical assistance and related practices studies by the manner in which technical assistance practices were related to the study and evaluation outcomes.

As part of our review, technical assistance was conceptualized as an implementation practice that would be expected to be a major determinant of the degree to which targeted intervention practices were adopted and used as part of program, organization, and systems change [1,9, 12]. According to Dunst, et al. [13], the fidelity of use of implementation practices would be expected to be related to variations in adoption and fidelity of use of intervention practices. As noted by Fixsen, et al. [12], "implementation processes [e.g., technical assistance]... should be described in sufficient detail such that independent observers can detect the presence and strength of the 'specific set of activities' related to the implementation". Technical assistance as described and investigated in this paper used a specific set of core elements as implementation practices to affect changes or improvements in intervention practices.

\section{CONCLUSION}

The importance of explicit attention to the fidelity of both technical assistance practices and intervention practices emerged as robust predictors of the effects of technical assistance. Future research on technical assistance would therefore benefit from explicit assessment of the fidelity of both implementation and intervention practices and the manner in which the two types of practices are related, in order to further our understanding of technical assistance-intervention practice relationships.

\section{ACKNOWLEDGEMENTS}

The preparation of this paper was supported, in part, by funding from the U.S. Department of Education, Office of Special Education Programs (No. 325B120004) for the Early Childhood Personnel Center, University of Connecticut Health Center (Mary Beth Bruder, Principal Investigator). The contents and opinions expressed, however, are those of the authors and do not necessarily reflect the policy or official position of the U.S. Department of Education, Office of Special Education Programs, University of Connecticut Health Center, or the Early Childhood Personnel Center, and no endorsement should be inferred or implied.

Review of the effects of technical assistance on program, organization, and system change (Carl J. Dunst) 


\section{REFERENCES}

[1] K. A. Blase. (2009, 2018/05/29). Technical assistance to promote service and system change. Roadmap to Effective Intervention Practices \#4, 1-15. Available: https://files.eric.ed.gov/fulltext/ED577840.pdf

[2] R. F. Putnam, J. K. Luiselli, and G. L. Jefferson, "Expanding technical assistance consultation to public schools: District-wide evaluation of instructional and behavior support practices for students with developmental disabilities," Child \& Family Behavior Therapy, vol. 24, pp. 113-128, 2002.

[3] J. A. Durlak and E. P. DuPre, "Implementation matters: A review of research on the influence of implementation on program outcomes and the factors affecting implementation," American Journal of Community Psychology, vol. 41, pp. 327-350, 2008.

[4] G. R. West, S. P. Clapp, E. M. Davidson Averill, and W. Cates, Jr., "Defining and assessing evidence for the effectiveness of technical assistance in furthering global health," Global Public Health, vol. 7, pp. 915-930, 2012.

[5] J. Katz and A. Wandersman, "Technical assistance to enhance prevention capacity: A research syntheses of the evidence base," Prevention Science, vol. 17, pp. 417-428, 2016.

[6] D. C. Meyers, J. A. Durlak, and A. Wandersman, "The quality implementation framework: A synthesis of critical steps in the implementation process," American Journal of Community Psychology, vol. 50, pp. 462-480, 2012.

[7] W. C. Livingood, A. H. Peden, G. H. Shah, N. A. Marshall, K. M. Gonzalez, R. B. Toal, et al. (2015, Comparison of practice based research network based quality improvement technical assistance and evaluation to other ongoing quality improvement efforts for changes in agency culture. BMC Health Services Research 15, 300-310.

[8] E. R. Babbie, The practice of social research, 12th ed. Belmont, CA: Wadsworth, 2009.

[9] A. Wandersman, V. H. Chien, and J. Katz. (2012, Toward an evidence-based system for innovation support for implementing innovations with quality: Tools, training, technical assistance, and quality assurance/quality improvement. American Journal of Community Psychology.

[10] R. M. Bertram, J. C. Suter, E. J. Bruns, and K. E. O'Rourke, "Implementation research and wraparound literature: Building a research agenda," Journal of Child and Family Studies, vol. 20, pp. 713-725, 2011.

[11] C. J. Dunst, K. Annas, H. Wilkie, and D. W. Hamby, "Scoping review of the core elements of technical assistance models and frameworks," in Manuscript under review, ed, 2018.

[12] D. L. Fixsen, S. F. Naoom, K. A. Blase, R. M. Friedman, and F. Wallace, Implementation research: A synthesis of the literature. Chapel Hill, NC: University of North Carolina. Retrieved from https://fpg.unc.edu/node/4445, 2005.

[13] C. J. Dunst, C. M. Trivette, and M. Raab, "An implementation science framework for conceptualizing and operationalizing fidelity in early childhood intervention studies," Journal of Early Intervention, vol. 35, pp. 85-101, 2013.

[14] J. Leeman, L. Calancie, M. C. Kegler, C. T. Escoffery, A. K. Herrmann, E. Thatcher, et al., "Developing theory to guide building practitioners' capacity to implement evidence-based interventions," Health Education \& Behavior, vol. 44, pp. 59-69, 2017.

[15] D. W. Chapman and A. S. Moore, "A meta-look at meta-studies of the effectiveness of development assistance to education," International Review of Education, vol. 56, pp. 547-565, 23/05/2018 2010.

[16] J. R. Olson, "A formative evaluation of a coach-based technical assistance model for youth- and family-focused programming," Evaluation and Program Planning, vol. 67, pp. 29-37, 2018.

[17] F. D. Butterfoss, "The coalition technical assistance and training framework: Helping community coalitions help themselves," Health Promotion Practice, vol. 5, pp. 118-126, 2018/05/29 2004.

[18] P. Florin, R. Mitchell, and J. Stevenson, "Identifying training and technical assistance needs in community coalitions: A developmental approach," Health Education Research: Theory and Practice, vol. 8, pp. 417-432, 1993.

[19] M. Chinman, G. Hannah, A. Wandersman, P. Ebener, S. B. Hunter, P. Imm, et al., "Developing a community science research agenda for building community capacity for effective preventive interventions," American Journal of Community Psychology, vol. 35, pp. 143-157, 2005.

[20] L. M. Hodge and K. M. T. Turner, "Sustained implementation of evidence-based programs in disadvantaged communities: A conceptual framework of supporting factors," American Journal of Community Psychology, vol. 58, pp. 192-210, 2016.

[21] D. L. Fixsen, K. A. Blase, R. Horner, and G. Sugai., "Intensive technical assistance," Scaling up: Brief February(2), 1-4. Available: https://sisep.fpg.unc.edu/sites/sisep.fpg.unc.edu/files/resources/SISEP-Brief2Intensive-TA.pdf, 2009

[22] D. Fixsen, K. A. Blase, R. Horner, and G. Sugai, "Scaling up.," in Scaling up: Brief \#1, ed Chapel Hill, NC: University of North Carolina, FPG, SISEP. Retrieved from https://sisep.fpg.unc.edu/sites/sisep.fpg.unc.edu/files/resources/SISEP-Brief1-Scalingup.pdf 2013.

[23] T. Hak and J. Dul, "Pattern matching," in Encyclopedia of case study research, A. J. Mills, G. Durepos, and E. Wiebe, Eds., ed Thousand Oaks, CA: Sage, 2010, pp. 664-666.

[24] W. M. K. Trochim, "Pattern matching, validity, and conceptualization in program evaluation," Evaluation Review, vol. 9, pp. 575-604, 1985.

[25] P. Chamberlain, C. H. Brown, and L. Saldana, "Observational measure of implementation progress in community based settings: The stages of implementation completion (SIC)," Implementation Science, vol. 6, pp. 1-8, 2011.

[26] R. H. Horner, A. W. Todd, T. Lewis-Palmer, L. K. Irvin, G. Sugai, and J. B. Boland, "The school-wide evaluation tool set (SET): A research instrument for assessing school-wide positive behavior support," Journal of Positive Behavior Interventions, vol. 6, pp. 3-12, 2004.

Int. J. Eval. \& Res. Educ. Vol. 8, No. 2, June 2019: 330 - 343 
[27] M. McInerney and J. L. Hamilton, "Elementary and middle schools technical assistance center: An approach to support the effective implementation of scientifically based practices in special education," Exceptional Children, vol. 73 , pp. $242-255,2007$.

[28] G. Sugai, A. W. Todd, and R. Horner, Effective behavior support (EBS) survey: Assessing and planning behavior supports in schools. Eugene, OR: University of Oregon, 2000.

[29] W. C. Cooley, J. W. McAllister, K. Sherrieb, and R. E. Clark, "The Medical Home Index: Development and validation of a new practice-level measure of implementation of the medical home model," Ambulatory Pediatrics, vol. 3, pp. 173-180, 2003.

[30] L. Fox and P. Snyder, Teaching Pyramid Observation Tool (TPOT $\left.{ }^{\mathrm{TM}}\right)$ for Preschool Classrooms Manual, Research Edition. Baltimore: Paul H. Brookes, 2014.

[31] R. C. Pianta, K. M. La Paro, and B. Hamre, Classroom assessment scoring system (CLASS): Pre-K version. Baltimore: Paul H. Brookes, 2008.

[32] D. S. Ward, S. Mazzucca, C. McWilliams, and D. Hales., "Use of the environment and policy evaluation and observation as a self-report instrument (EPAO-SR) to measure nutrition and physical activity environments in child care settings: Validity and reliability evidence," International Journal of Behavioral Nutrition and Physical Activity 12. Available: https://ijbnpa.biomedcentral.com/track/pdf/10.1186/s12966-015-0287-0, 2015

Review of the effects of technical assistance on program, organization, and system change (Carl J. Dunst) 


\begin{tabular}{|c|c|c|c|}
\hline \multicolumn{4}{|c|}{$\begin{array}{c}\text { Appendix A } \\
\text { Technical Assistance Studies and Evaluations }\end{array}$} \\
\hline no & author & Title & source \\
\hline 1 & $\begin{array}{l}\text { Abell, E., Arsiwalla, } \\
\text { D. D., Putnam, R. I., } \\
\text { \& Miller, E. B. }\end{array}$ & $\begin{array}{l}\text { Mentoring and facilitating professional } \\
\text { engagement as quality enhancement } \\
\text { strategies: An overview and evaluation of the } \\
\text { family child care partnerships program. }\end{array}$ & Child Youth Care Forum, 2014, No. 43 \\
\hline 2 & $\begin{array}{l}\text { Becker, K. } \quad \text { D., } \\
\text { Bradshaw, C. P., } \\
\text { Domitrovich, C. E., \& } \\
\text { Ialongo, N. S. }\end{array}$ & $\begin{array}{l}\text { Coaching teachers to improve } \\
\text { implementation of the good behavior game }\end{array}$ & $\begin{array}{l}\text { Administration and Policy in Mental Health, 2013, } \\
\text { No. } 40\end{array}$ \\
\hline 3 & $\begin{array}{l}\text { Berry, S., Barovechio, } \\
\text { P., Mabile, E., \& } \\
\text { Tran, T. }\end{array}$ & $\begin{array}{l}\text { Enhancing state medical home capacity } \\
\text { through a care coordination technical } \\
\text { assistance model. }\end{array}$ & Maternal and Child Health Journal, 2017, No. 21 \\
\hline 4 & $\begin{array}{l}\text { Bradshaw, C. } \\
\text { Mitchell, M. M., } \\
\text { Leaf, P. J. }\end{array}$ & $\begin{array}{l}\text { Examining the effects of schoolwide positive } \\
\text { behavioral interventions and supports on } \\
\text { student outcomes : Results from a } \\
\text { randomized controlled effectiveness trial in } \\
\text { elementary schools }\end{array}$ & $\begin{array}{l}\text { Journal of Positive Behavior Interventions, 2010, No. } \\
12\end{array}$ \\
\hline 5 & $\begin{array}{l}\text { Brown, C. H., } \\
\text { Chamberlain, P., } \\
\text { Saldana, L., Padgett, } \\
\text { C., Wang, W., \& } \\
\text { Cruden, G. }\end{array}$ & $\begin{array}{l}\text { Evaluation of two implementation strategies } \\
\text { in } 51 \text { child county public service systems in } \\
\text { two states: Results of a cluster randomized } \\
\text { head-to-head implementation trial. }\end{array}$ & Implementation Science, 2014 No. 9 \\
\hline 6 & $\begin{array}{l}\text { Chinman, M., Ebener, } \\
\text { P., Malone, P. S., } \\
\text { Cannon, J., D'Amico, } \\
\text { E. J., \& Acosta, J. }\end{array}$ & $\begin{array}{l}\text { Testing implementation support for } \\
\text { evidence-based programs in community } \\
\text { settings: A replication cluster-randomized } \\
\text { trial of Getting To Outcomes. }\end{array}$ & Implementation Science, 2018, No. 13 \\
\hline 7 & 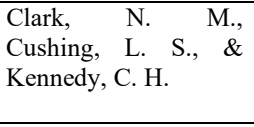 & $\begin{array}{l}\text { An intensive onsite technical assistance } \\
\text { model to promote inclusive educational } \\
\text { practices for students with disabilities in } \\
\text { middle school and high school. }\end{array}$ & $\begin{array}{l}\text { Research \& Practice for Persons with Severe } \\
\text { Disabilities, 2014, No. 29(4) }\end{array}$ \\
\hline 8 & $\begin{array}{l}\text { Cowley, K. S., Nilsen, } \\
\text { K. L., \& Ceperley, P. } \\
\text { E. }\end{array}$ & $\begin{array}{l}\text { Evaluation of a high-need school district's } \\
\text { organizational capacity for change. }\end{array}$ & $\begin{array}{lcr}\text { Charleston, } & \text { WV: } & \text { AEL } \\
\text { https://archive.org/details/ERIC_ED438991/page/n15. }\end{array}$ \\
\hline 9 & $\begin{array}{l}\text { Domitrovich, C. } \text { E., } \\
\text { Gest, S. D., Gill, S., } \\
\text { Bierman, K. L., } \\
\text { Welsh, J. A., \& Jones, } \\
\text { D. }\end{array}$ & $\begin{array}{l}\text { Fostering high-quality teaching with an } \\
\text { enriched curriculum and professional } \\
\text { development support: The Head Start REDI } \\
\text { program }\end{array}$ & $\begin{array}{l}\text { American Educational Research Journal, } 2009 \text { No. } \\
\text { 46(2), }\end{array}$ \\
\hline 10 & $\begin{array}{l}\text { Dunst, C. J., \& Raab, } \\
\text { M. }\end{array}$ & $\begin{array}{l}\text { Practitioners' self-evaluations of contrasting } \\
\text { types of professional development }\end{array}$ & Journal of Early Intervention, 2010 No. 32 \\
\hline 11 & $\begin{array}{l}\text { Dunst, C. J., Trivette, } \\
\text { C. M., \& Deal, A. G. }\end{array}$ & $\begin{array}{l}\text { Effects of in-service training on early } \\
\text { intervention practitioners' use of family } \\
\text { systems intervention practices in the USA }\end{array}$ & Professional Development in Education, 2011 No. 37 \\
\hline 12 & $\begin{array}{lrr}\text { Early, } & \text { D. } & \text { M., } \\
\text { Maxwell, } & \text { K. } & \text { L., } \\
\text { Ponder, } & \text { B. D., \& } & \text { Pan, } \\
\text { Y. }\end{array}$ & $\begin{array}{l}\text { Improving teacher-child interactions: A } \\
\text { randomized controlled trial of Making the } \\
\text { Most of Classroom Interactions and My } \\
\text { Teaching Partner professional development } \\
\text { models }\end{array}$ & Early Childhood Research Quarterly, 2017, No 38 \\
\hline 13 & $\begin{array}{l}\text { Fox, L., Hemmeter, } \\
\text { M., Snyder, P., } \\
\text { Binder, D. P., \& } \\
\text { Clarke, S. }\end{array}$ & $\begin{array}{l}\text { Coaching early childhood special educators } \\
\text { to implement a comprehensive model for } \\
\text { promoting young children's social } \\
\text { competence }\end{array}$ & $\begin{array}{l}\text { Topics in Early Childhood Special Education, 2011, } \\
\text { No. 31(3) }\end{array}$ \\
\hline 14 & $\begin{array}{l}\text { Horner, R. H., Sugai, } \\
\text { G., Smolkowski, K., } \\
\text { Eber, L., Nakasato, J., } \\
\text { Todd, A. W., \& } \\
\text { Esperanza, J. }\end{array}$ & 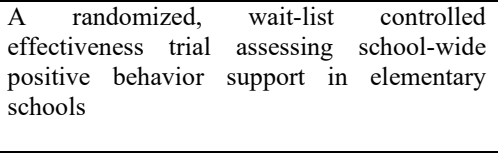 & $\begin{array}{l}\text { Journal of Positive Behavior Interventions, 2009, No. } \\
\text { 11(3) }\end{array}$ \\
\hline 15 & $\begin{array}{lrr}\text { Landry, } & \text { S. } & \text { H., } \\
\text { Anthony, J. } & \text { L., } \\
\text { Swank, P. R., \& } \\
\text { Monseque-Bailey, P. }\end{array}$ & $\begin{array}{l}\text { Effectiveness of comprehensive professional } \\
\text { development for teachers of at-risk } \\
\text { preschoolers }\end{array}$ & Journal of Educational Psychology, 2009, No 101(2) \\
\hline 16 & $\begin{array}{lrr}\text { LaRowe, } & \text { T. } & \text { L., } \\
\text { Tomayko, } & \text { E. } & \text { J., } \\
\text { Meinen, } & \text { A. } & \text { M., } \\
\text { Hoiting, J., } & \text { Saxler, C., } \\
\text { Cullen, } & \text { B., } & \& \\
\text { Initiative, } & \text { W. E. C. } \text { O. } \\
\text { P. } & \end{array}$ & $\begin{array}{l}\text { Active early: One-year policy intervention to } \\
\text { increase physical activity among early care } \\
\text { and education programs in Wisconsin }\end{array}$ & BMC Public Health, 2016, No. 16 \\
\hline
\end{tabular}

Int. J. Eval. \& Res. Educ. Vol. 8, No. 2, June 2019: 330 - 343 


\begin{tabular}{|c|c|c|c|}
\hline 17 & $\begin{array}{l}\text { Lassen, S. R., Steele, } \\
\text { M. M., \& Sailor, W. }\end{array}$ & $\begin{array}{l}\text { The relationship of school-wide positive } \\
\text { behavior support to academic achievement in } \\
\text { an urban middle school }\end{array}$ & Psychology in the Schools, 2006, No. 43(6) \\
\hline 18 & $\begin{array}{l}\text { McDougal, J. } \\
\text { Clonan, S. M., } \\
\text { Martens, B. K. }\end{array}$ & $\begin{array}{l}\text { Using organizational change procedures to } \\
\text { promote the acceptability of prereferral } \\
\text { intervention services: The school-based } \\
\text { intervention team project }\end{array}$ & School Psychology Quarterly, 2000, No. 15(2) \\
\hline 19 & $\begin{array}{l}\text { McInerney, M., \& } \\
\text { Hamilton, J. L. }\end{array}$ & $\begin{array}{l}\text { Elementary and middle schools technical } \\
\text { assistance center: An approach to support the } \\
\text { effective implementation of scientifically } \\
\text { based practices in special education }\end{array}$ & Exceptional Children, 2007, No. 73 \\
\hline 20 & $\begin{array}{l}\text { Nelson, J. R., } \\
\text { Martella, R. M., \& } \\
\text { Marchand-Martella, } \\
\text { N. }\end{array}$ & $\begin{array}{l}\text { Maximizing student learning: The effects of } \\
\text { a comprehensive school-based program for } \\
\text { preventing problem behaviors }\end{array}$ & $\begin{array}{l}\text { Journal of Emotional and Behavioral Disorders, } \\
\text { 2002, No. 10(3) }\end{array}$ \\
\hline 22 & $\begin{array}{l}\text { Newton, J. S., Horner, } \\
\text { R. H., Algozzine, B., } \\
\text { Todd, A. W., \& } \\
\text { Algozzine, K. M. }\end{array}$ & $\begin{array}{l}\text { A randomized wait-list controlled analysis of } \\
\text { team-initiated problem solving processes }\end{array}$ & Journal of School Psychology, 2012, No. 50 \\
\hline 23 & $\begin{array}{l}\text { Ray, M. L., Wilson, } \\
\text { M. M., Wandersman, } \\
\text { A., Meyers, D. C., \& } \\
\text { Katz, J. }\end{array}$ & $\begin{array}{l}\text { Using a training-of-trainers approach and } \\
\text { proactive technical assistance to bringing } \\
\text { evidence based programs to scale: An } \\
\text { operationalization of the interactive systems } \\
\text { framework's support system }\end{array}$ & $\begin{array}{l}\text { American Journal of Community Psychology, 2012, } \\
\text { No. 50(3) }\end{array}$ \\
\hline 24 & $\begin{array}{l}\text { Ross, S. W., } \quad \text { \& } \\
\text { Horner, R. H. }\end{array}$ & $\begin{array}{l}\text { Bully prevention in positive behavior } \\
\text { support: Preliminary evaluation of third-, } \\
\text { fourth-, and fifth-grade attitudes toward } \\
\text { bullying }\end{array}$ & $\begin{array}{l}\text { Journal of Emotional and Behavioral Disorders, } \\
\text { 2014, No. 22(4) }\end{array}$ \\
\hline
\end{tabular}

